\title{
USE OF THROMBECTOMY ASPIRATION IN THE TREATMENT OF ACUTE VENOUS THROMBOSIS
}

Anna Szarnecka-Sojda, Jarosław Miszczuk

Provincial Hospital in Kielce, Vascular Surgery Clinic, Kielce, Poland

\author{
ORIGINAL PAPER
}

Phlebological Review 2018; 26, 1: 10-18

DOI: https://doi.org/10.5114/pr.2018.76384

Submitted: 28.12 .2017

Accepted: 29.01.2018

\author{
Address for correspondence \\ Anna Szarnecka-Sojda \\ Provincial Hospital in Kielce \\ Vascular Surgery Clinic \\ 45 Grunwaldzka St. \\ 25-736 Kielce, Poland \\ e-mail: asojda@tlen.pl
}

Key words: acute vein thrombosis, post-thrombotic syndrome, transcatheter thrombolysis, mechanical thrombectomy, aspiration thrombectomy.

\section{INTRODUCTION}

Venous thrombosis is an acute thrombotic event arising in the venous placenta manifested by: deep vein thrombosis (DVT), pulmonary embolism (PE) or both. The most common source of embolic material are veins of the lower limbs, with $50 \%$ of patients showing no symptoms of the disease. In Poland, about 57,000 new cases of DVT and about 36,000 cases of PE are reported every year. Proximal thrombosis gives symptoms only in $40-50 \%$ of cases, distal thrombosis located below the knee joint gap gives symptoms in only $5-15 \%$. The first symptom of venous thromboembolism may be pulmonary embolism. The mortality rate for untreated PE is $30 \%$ in the first 30 days of the disease, and despite correct treatment $3-15 \%$ of stable patients with right ventricular dysfunction die.
In European Union countries, 543,454 people die each year due to venous thromboembolism and its complications, i.e. more than in total due to: breast cancer, prostate cancer, HIV/AIDS, and road accidents.

The primary goal of acute DVT treatment is:

1) prevention of thrombus development,

2) prevention of acute complications mainly of pulmonary embolism and acute limb ischaemia (phlegmasia alba and phlegmasia cerulea),

3) prevention of late complications such as post-thrombotic syndrome,

4) treatment of symptoms to reduce pain and swelling of the limb.

Anticoagulation remains the gold standard for DVT treatment, but pharmacomechanical removal of thrombi, especially from the proximal segments of the lower and upper limb veins, may favour the valve function and reduce the incidence of post-thrombotic syndrome 
(PTS). At least half of all patients with DVT of the lower limbs treated exclusively with anticoagulation develop long-term complications due to post-thrombotic syndrome.

New methods of treating deep vein thrombosis beyond standard treatment have appeared along with the growing number of devices designed to remove blood clots on the market. Treatments bringing very good results include transcutaneous interventions with the use of a thrombolytic catheter (PCDT) and mechanical thrombectomies (PMT), including aspiration.

Society for Vascular Surgery Documents points to the possibility of early removal of clots using unconventional methods in selected patients with the first acute episode and symptoms lasting less than 14 days, with low risk of bleeding and acceptable life expectancy, especially when symptoms of phlegmasia cerulea or phlegmasia alba appear. The clot should be located in the iliofemoral segment. Similar rules apply to the choice of therapy in young patients with axillary vein thrombosis and sections of deep veins proximal to it. In the above situations, pharmacological and pharmacomechanical percutaneous approaches are first suggested [1].

This year Konsensus Polski 2017, developed on the basis of the ACCP Antithrombotic Therapy for Venous Thromboembolic Diseases 2016 guidelines, presented the expert opinion on the treatment of acute proximal limb and upper limb vein thrombosis, accepting the use of transcatheter thrombolysis in selected patients. Factors supporting the decision to take this method of treatment are: symptoms lasting less than 14 days, good general condition of the patient, low risk of bleeding, expected survival of more than one year, and an experienced and trained team performing the procedure [2].

Percutaneous mechanical thrombectomy is used to dissolve, fragment, and aspirate thrombus and congestion in patients with acute massive DVT or PE. This method is best suited for the treatment of fresh thrombi formed for less than 10-14 days, and its effectiveness in longer-lasting thromboembolism is less predictable.

There are also no unambiguous data on the impact of transcatheter mechanical interventions on the vessel wall, venous valves, and pulmonary vessels in short- and longterm observation; therefore, obtaining reliable scientific data based on the medicine of facts is necessary to clearly define the role of this method [2].

There are many reports suggesting that systemic thrombolysis, surgical thrombectomy, and percutaneous pharmacomechanical thrombectomy may reduce the onset of PTS.

Multicentre randomised trials indicate that the use of mechanical thrombolysis or thrombolysis directed by a catheter in the iliac and femoral section will have an important role in the treatment of acute DVT in the future [3-7].
Positive effects were also observed when using this method as initial therapy in patients with or without MTS (May-Thurner Syndrome), although thrombosis in the course of MTS has a different aetiology than DVT [8-10].

The use of alteplase and other thrombolytic preparations has numerous, well-known limitations $[2,4]$.

Percutaneous mechanical thrombectomy (PMT) allows thrombus removal if the patient has contraindications to systemic thrombolysis, as an alternative method without the administration of lytic drugs [4].

The following devices are used to remove blood clots - some of them contain mechanisms to macerate the thrombus, some of them simultaneously macerate and remove clots. These include Angiojet-Zelante; AngioJet-Solent; Cleaner XT; Cleaner 15 (rotatory thrombectomy); Trelis, Indigo, Angio Vac [11-14].

Maceration of thrombi promotes pulmonary embolism and other dangerous complications, so patients with low respiratory reserve and cardiac-respiratory failure have potential contraindications to this type of intervention.

There are very few randomised data from which conclusions can be drawn regarding the use of pharmacomechanical thrombectomies and other invasive treatments for DVT.

Great hopes are associated with the announcement of the results of the ATTRACT trial, evaluating the development of post-thrombotic syndrome in patients with proximal thrombosis in the iliofemoral segment. Two methods of treatment in this group were compared: pharmacomechanical thrombectomy combined with thrombolysis, and standard treatment with traditional anticoagulants. Preliminary reports presented after two years of observation at the Society of Interventional Radiology in 2017 mention the lack of significant differences in the occurrence of PTS assessed according to the Villalta scale in the period between six and 24 months after the thrombosis incident in the examined groups ( $46.7 \%$ vs. $48.2 \%$ ).

The PCDT method caused more bleeding complications than traditional anticoagulation ( $12.5 \%$ vs. $8.5 \%)$. However, there was a significant reduction in severe PTS in patients treated with PCDT with thrombosis in the iliofemoral section compared to the femoropopliteal segment (17.9\% vs. $23.7 \%)$ [15].

The use of this unconventional DVT treatment method requires proper selection of patients. The long-term benefits of this method of treatment are seen in young people $<65$ years of age, active, symptomatic, with thrombosis in the iliofemoral segment and low risk of bleeding $[1-3,14]$.

The AngioJet system removes the clot by maceration, but at the same time it haemolyses the red blood cells and leads to haemoglobinuria, hyperpotassaemia, and kidney damage. Rhythm disturbances in the form of bradycardia, the mechanism of which is unknown, have also been 
recorded. Overly aggressive mechanical thrombectomy may damage the venous valves [4].

Aspiration thrombectomy with thrombus removal is a type of thrombectomy supported by a vacuum pump, which uses extracorporeal venous circulation and allows for extended aspiration thrombectomy without the risk of blood loss. Penumbra Indigo catheters have been used so far in sucking thrombi using the aspiration method with negative pressure in cerebral and coronary circulation. Therefore, there are no data available to indicate the safety and efficacy of this device in the treatment of acute deep vein thrombosis $[4,16]$.

\section{MATERIAL AND METHODS}

The Penumbra Indigo System device in combination with transcatheter thrombolysis was used for the treatment of acute proximal venous thrombosis in selected patients hospitalised in the Department of Vascular Surgery, Provincial Hospital Complex in Kielce, from January 1 to June 30, 2017.

During this period 24 patients were hospitalised due to thrombosis, in six patients non-standard methods were used, and the remaining 18 people were treated traditionally with anticoagulants.

\section{Case 1}

Female A.P., 19 years old, was admitted with a fever of 38 degrees, pain, and swelling of the upper left limb lasting for a week. Symptoms had intensified over the previous

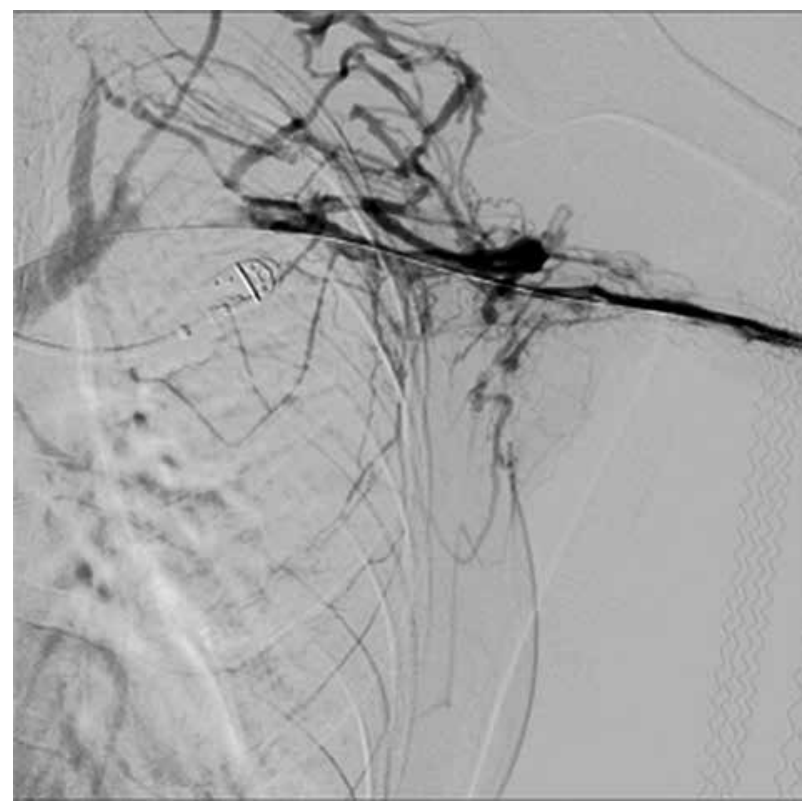

Fig. 1. Case 1 - Venography before intervention; left upper limb: occlusion of subclavian vein, axillary, and brachial veins; visible collateral vessels
24 hours. The Doppler ultrasound examination revealed occluded subclavian, axillary, and brachial veins and partially occluded basilic vein. Unfractionated heparin in therapeutic dose was included in the treatment. Endoscopic diagnostics was performed, and after exclusion of fresh bleeding from the gastrointestinal tract on the seventh day of hospitalisation, the thrombus was suction-extracted by catheter CAT8 of the Indigo System from access via the brachial vein. The subclavian vein was cleared and an EPC $8 \times 80 \mathrm{~mm}$ stent was implanted at the residual stenosis site. Control Doppler ultrasound and phlebology showed complete patency of the subclavian vein. During the day, the swelling stopped and the network of superficial vessels decreased. The attempts of movement and chest CT (computed tomography) performed for the chest compression syndrome (thoracic outlet syndrome - TOS) confirmed the suspicion. Thrombectomy required transfusion of two units of red blood cells due to a decrease in haemoglobin below $7 \mathrm{~g} \%$. The patient was discharged home with a recommendation to take rivaroxaban $20 \mathrm{mg}$ per day for three months and acetylsalicylic acid $75 \mathrm{mg}$ once a day chronically. The duration of hospitalisation was eight days, extended due to the required diagnostics excluding bleeding. The treatment was performed on the seventh day of hospitalisation.

In the second stage of treatment, one month after the surgery, the first left rib, which caused TOS, was removed. Control tests; Doppler ultrasound performed after one, three, and five months from the event showed complete patency of the axillary and subclavian veins and partially brachial vein.

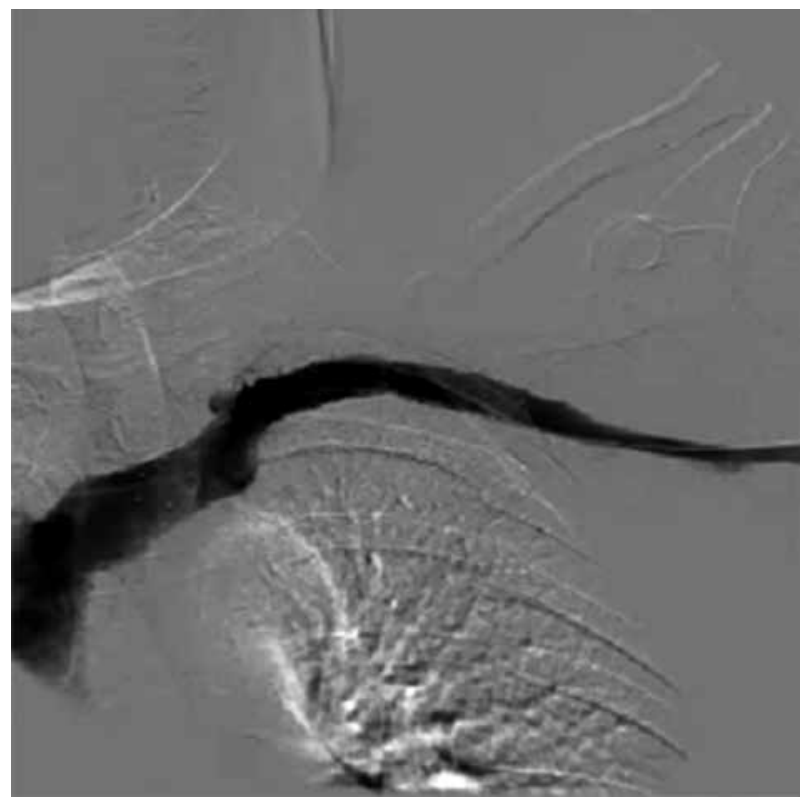

Fig. 2. Case 1 - Venography after intervention; visible flow in subclavian vein and axillary vein, vascular collaterals disappeared 


\section{Case 2}

Female B.B., 41 years old, referred from the rheumatology unit where she was treated for systemic lupus with an accompanying antiphospholipid syndrome, admitted with pain and swelling of the left lower limb persisting for 6-7 days. In ultrasound-Doppler iliac external and femoral vein thrombosis was diagnosed. The patient initially received low-molecular-weight heparin in a therapeutic dose. On the second day of hospitalisation, thrombectomy was performed using the CAT8 catheter of the Indigo system, the thrombus was pulled from the external and partially from the femoral vein, leaving the thrombolytic catheter for 24 hours with an alteplase infusion of $1 \mathrm{mg} / \mathrm{min}$ due to incomplete recanalisation. Dissolution of residual clots was obtained. Then rivaroxaban $20 \mathrm{mg}$ once a day and compression therapy were included. The patient was discharged home on the third day after the intervention and on day 6 of hospitalisation. Control Doppler ultrasound performed at one, three, and five months after the procedure showed complete patency of the external femoral and superficial femoral vein.

\section{Case 3}

Female P.N., 19 years old, admitted with a fever of 39 degrees, with pain of the lumbosacral region and the left lower limb in the thigh and calf range, accompanied by swelling, bruising, and widened network of superficial veins on the limb. The patient flew by plane about two weeks previously, she had used contraception for six months, and she had a family burden - her grandfather suffered from thrombosis.

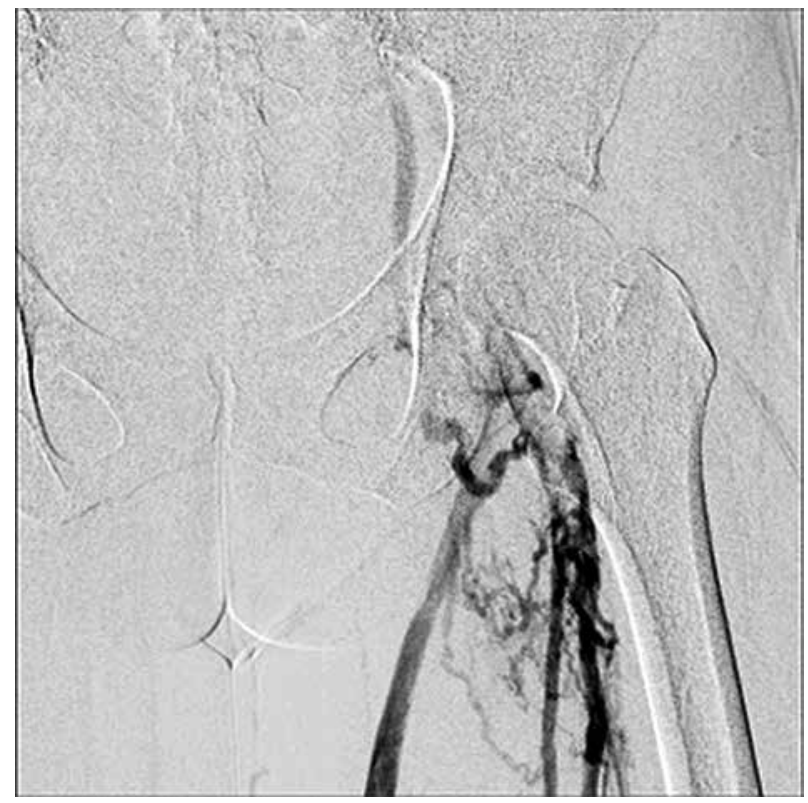

Fig. 3. Case 2 - Venography before intervention, occluded external iliac vein and femoral vein
In the Doppler ultrasound examination, complete closure of the left iliac vein by thrombus was found. Treatment with unfractionated heparin was instituted and venous phlebography was performed on the first day of hospitalisation, which showed the presence of thrombi in the common iliac and external iliac veins and parietally at the distal part of the main lower vein; the thrombus was induced by a CAT8 catheter of the Indigo System using the access via the left popliteal vein. The control venography showed a residual stenosis in the external iliac vein at its intersection with the right iliac artery. In this position an EPIC $12 \times 80 \mathrm{~mm}$ stent was implanted, obtaining an outflow through the whole vein and relief of symptoms of pain, swelling, and bruising of the limb.

After the intervention, a decrease in the value haemoglobin was observed, but not requiring blood transfusion. Subsequently, low molecular weight heparin was included in the treatment dose until the day of discharge from the hospital on the third day. Outpatient antithrombot-

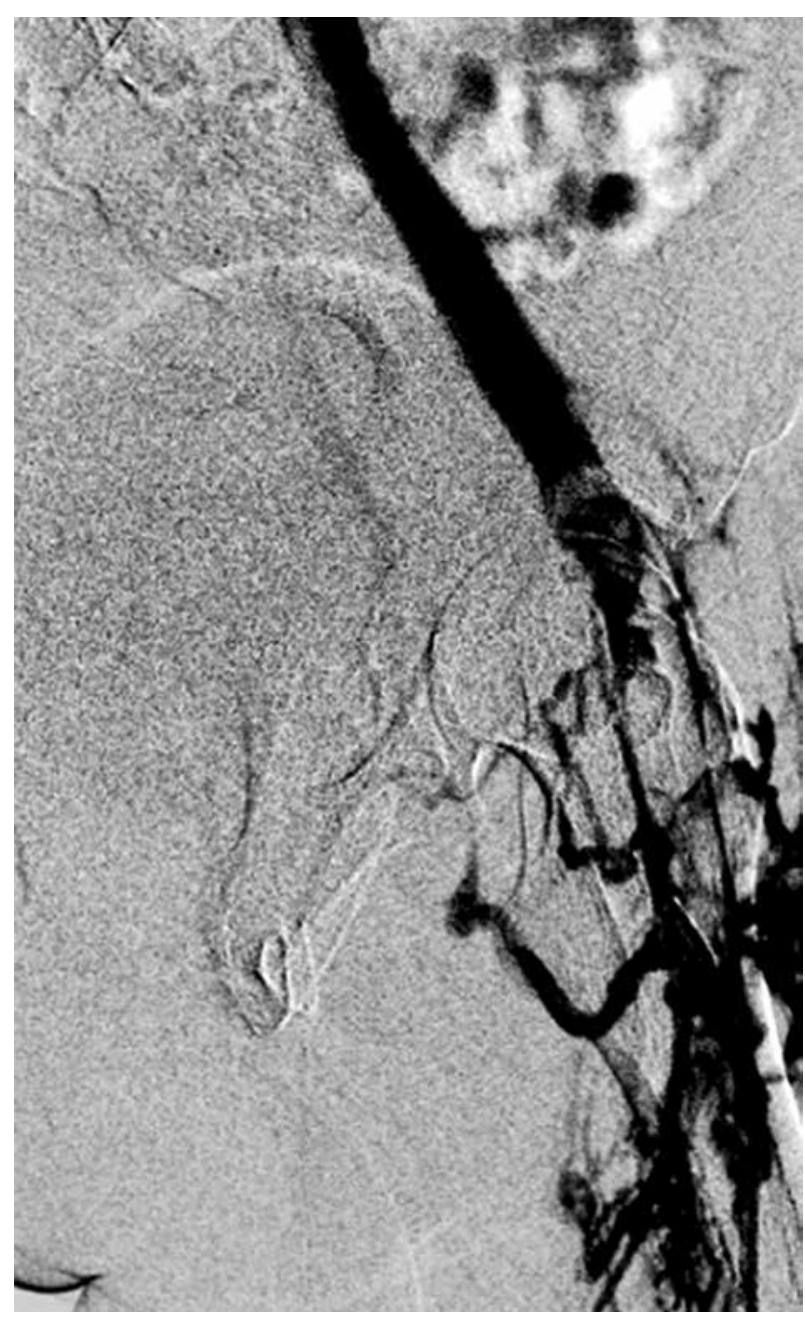

Fig. 4. Case 2 - Venography after the first stage of the procedure - external iliac vein with complete flow and incomplete recanalisation of the femoral vein 


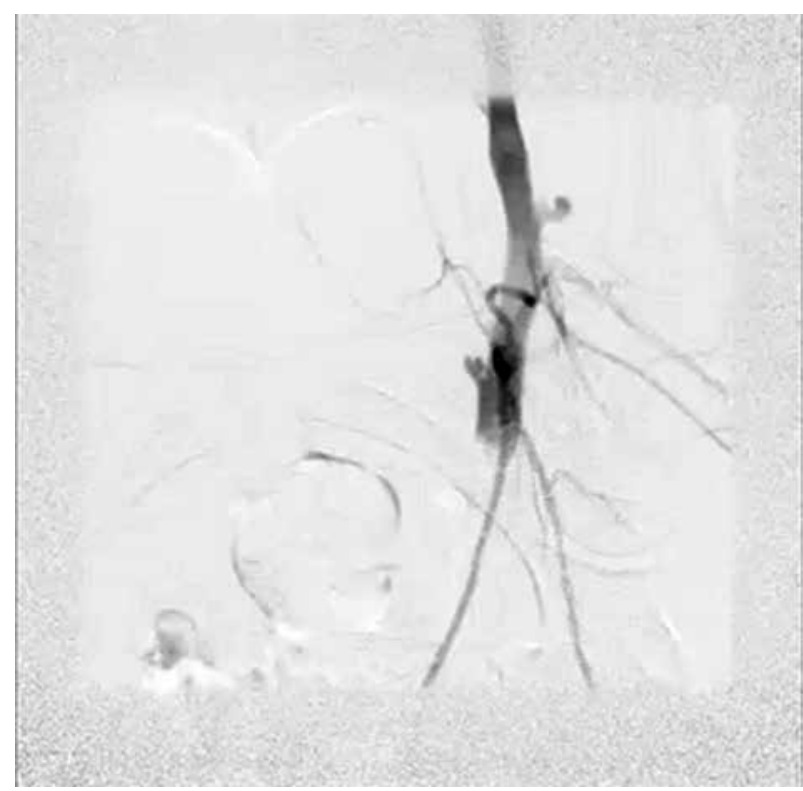

Fig. 5. Case 3 -Occlusion veins of the left iliac axis, position on the abdomen, venography before the procedure

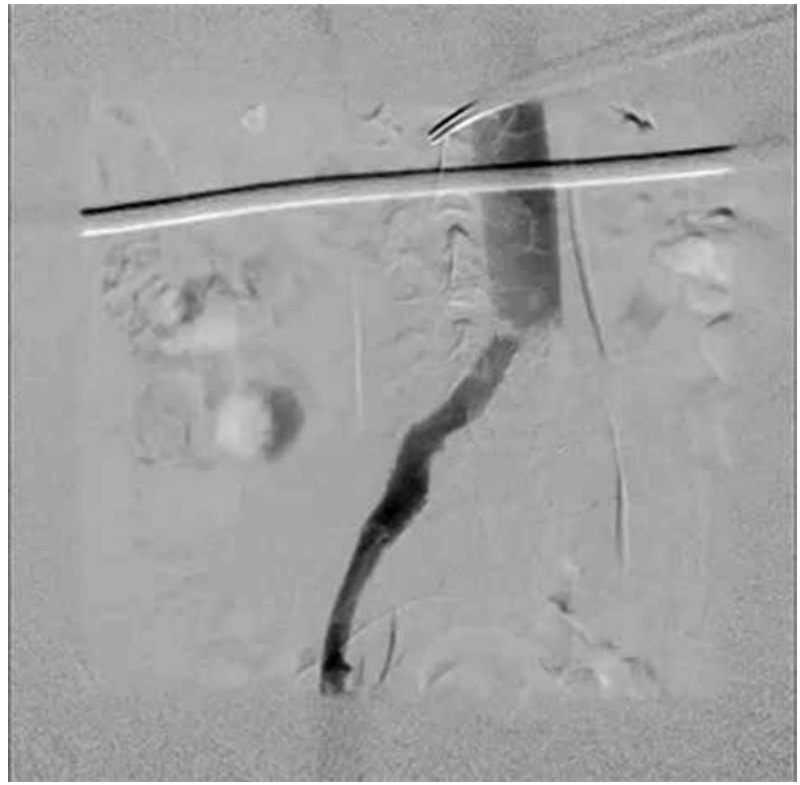

Fig. 6. Case 3 - Venography after procedure, visible flow in the common and external iliac veins

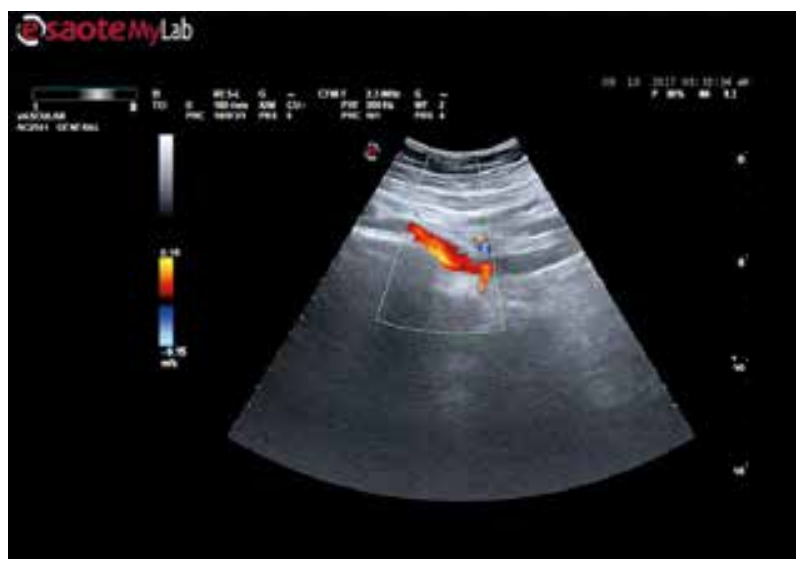

Fig. 7. Case 3 - Colour Doppler examination - control three months post-intervention. Visible flow in the external iliac vein and stent in it

ic treatment with rivaroxaban $20 \mathrm{mg}$ and acetylsalicylic acid $75 \mathrm{mg}$ per day was continued. Hospitalisation time was three days. Control Doppler ultrasound performed one, three, and five months after the incident showed full patency of left iliac and femoral veins.

\section{Case 4}

Male J.L., 72 years old, admitted due to severe pain, bruising, and swelling of the left lower limb, persisting for six days with suspected acute limb ischaemia. A few days earlier, he had been subjected to ablation of an additional route due to atrial fibrillation from the left femoral vein. Doppler ultrasound examination revealed thrombosis of the left common and external iliac veins and femoral vein. The anticoagulant treatment with unfractionated heparin was switched on, and on the first day of hospitalisation the thrombus was catheterised using a CAT8 catheter of the Indigo System from the common, external iliac, and femoral veins via the left popliteal vein, followed by angioplasty of residual stenosis in the external iliac vein, resulting in full patency of the left iliac axis and veins lower limb. Due to the loss of blood, the patient was transfused two units of red blood cells. He was discharged from the hospital on the fourth day of hospitalisation with the recommendation to continue treatment with rivaroxaban $20 \mathrm{mg}$ per day for a period of three months. A control Doppler ultrasound performed one, three, and five months after the procedure showed full patency of the veins. 


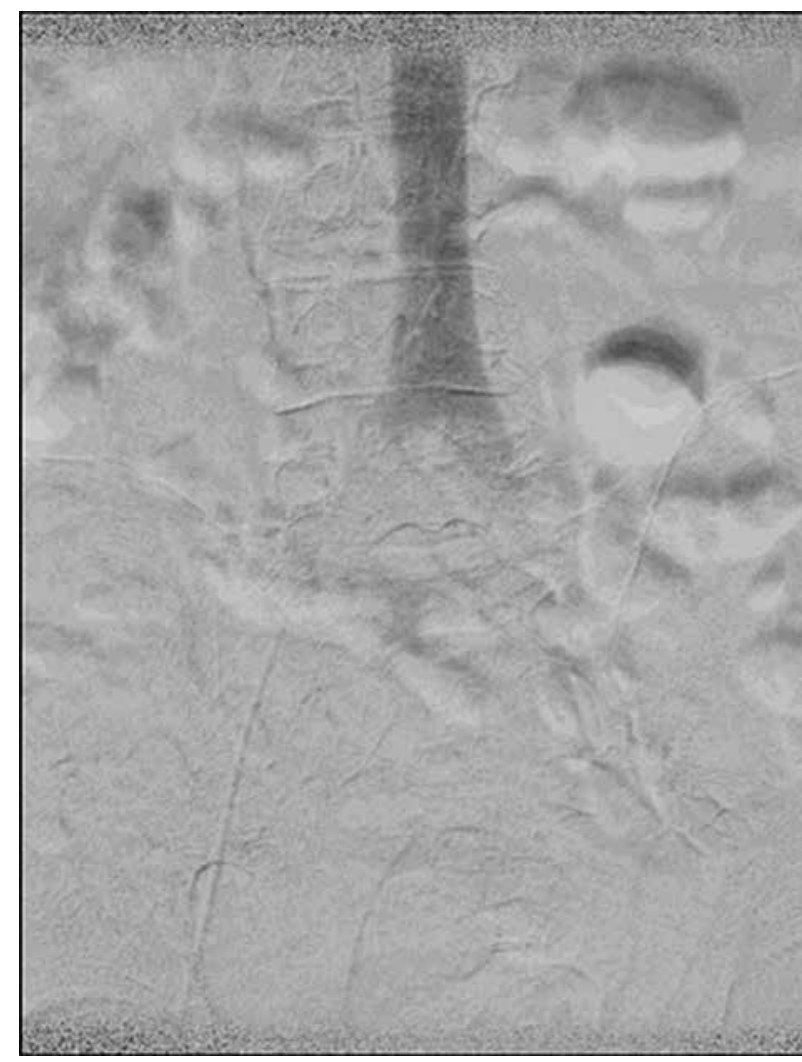

Fig. 8. Case 4 - Venography before intervention: obstructed left common and external iliac veins; position on the abdomen

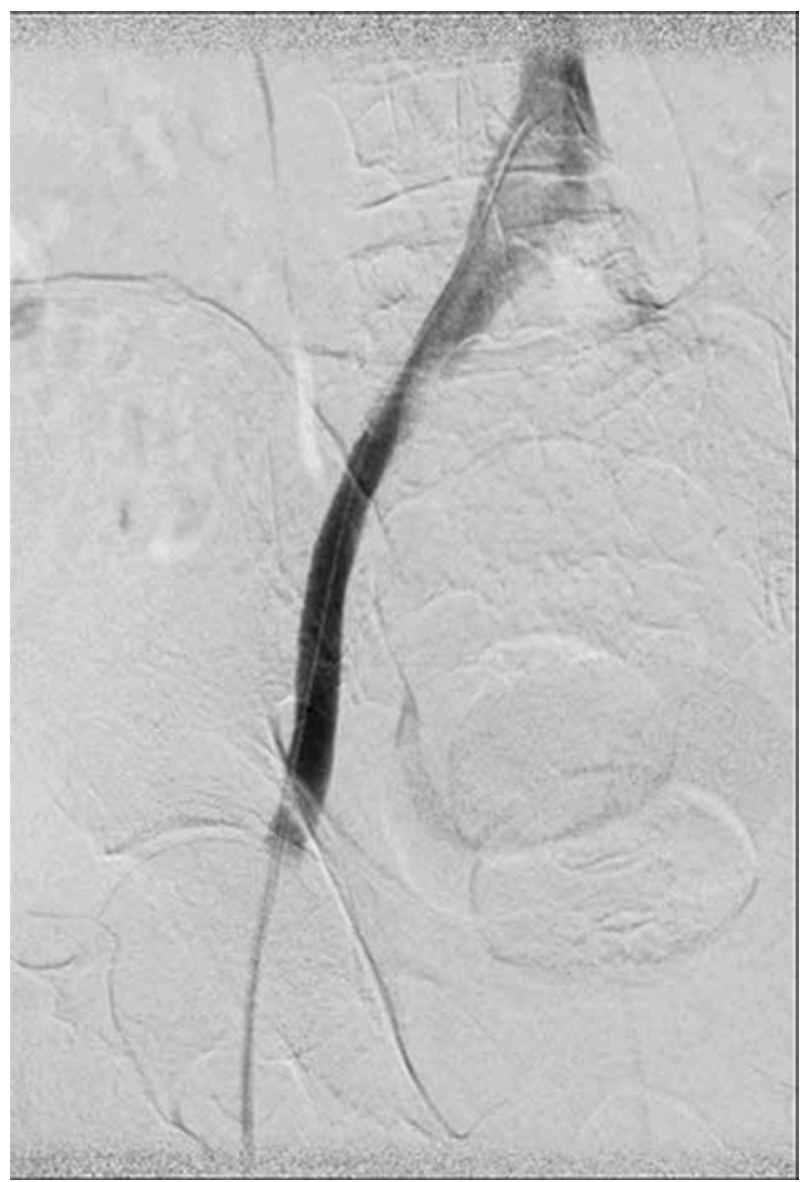

Fig. 9. Case 4 - Venography post-aspiration trombi, visible flow in the left common and external iliac veins, position on the abdomen

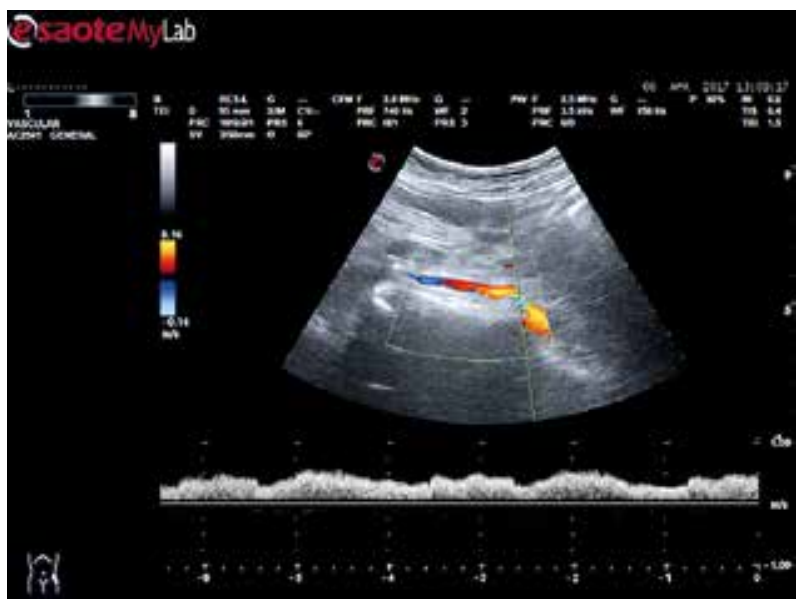

Fig. 10. Case 4 - Doppler ultrasound examination five months after intervention: iliac external and common veins

\section{Case 5}

Male T.W., 71 years old, admitted due to pain, swelling, and bruising of the left lower limb and elevated body temperature of 39 degrees, which persisted for four days. Six months earlier, due to a fracture of the right leg, he received a prophylactic dose of heparin for three months. In the past, he suffered from portal vein thrombosis associated with surgery of a tumour of the small intestine. In Doppler ultrasound examination, vein obstruction was observed in the left iliac axis: common, external iliac, and femoral veins. 


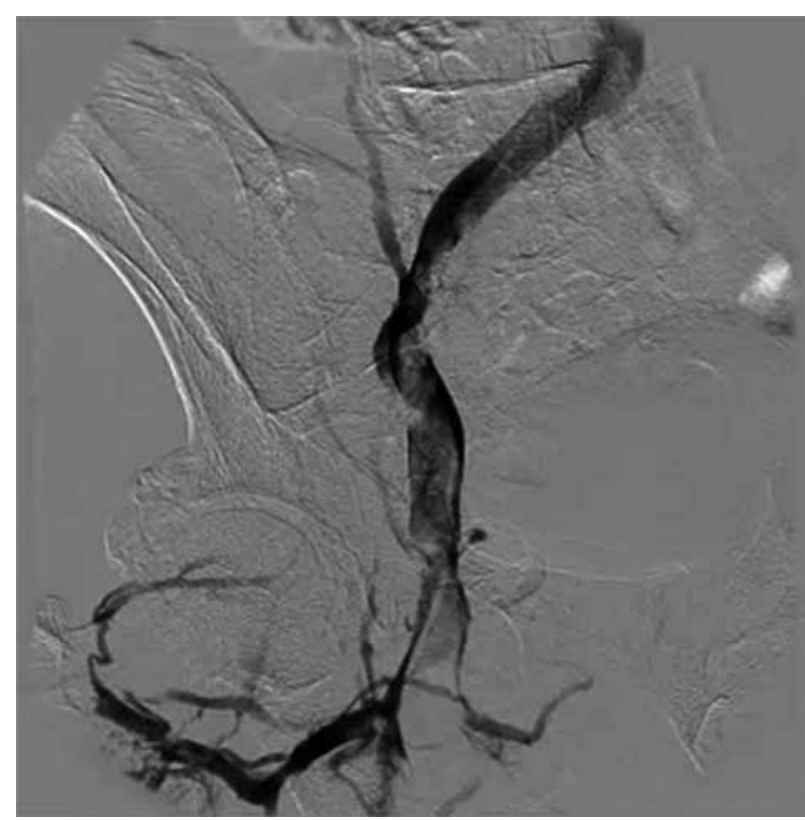

Fig. 11. Case 5 - Veins of the left iliac axis venography, partial resection after thrombotic aspiration in the position on the abdomen

Unfractionated heparin was included in the treatment, and on the third day of hospitalisation, due to severe ailments, the thrombus from the common, external iliac, and femoral veins was removed using a CAT6, 7F catheter from the Indigo System from the approach via the left popliteal vein. Because venous patency was not obtained in the control venography and residual constrictions were visualised, a 5-mg bolus of Actilyse was administered through the catheter without improvement, the catheter was left, and the Actilyse infusion was continued at $1 \mathrm{mg} /$ hour for 24 hours. Subsequent examination showed complete patency of left iliac axis veins and release of previous symptoms. He was discharged home with a recommendation to take rivaroxaban $20 \mathrm{mg}$ once day for three months and compression therapy. The hospitalisation time was four days. Control Doppler ultrasound after one, three, and five months of intervention showed complete patency of the veins and lack of discomfort.

\section{Case 6}

Female S.S., 64 years old, after partial nephrectomy due to a kidney tumour performed a week earlier, receiving typical anticoagulant prophylaxis, was admitted with swelling, pain, bruising of the left lower limb, and temperature of 38 degrees $C$ for 24 hours. Doppler ultrasound revealed blocked veins of the left iliac veins and femoral vein. Unfractionated heparin was included in the treatment, and an attempt was made to suck up the thrombus with an Indigo CAT6 catheter from the access via the left popliteal vein. No vein patency was achieved, and the

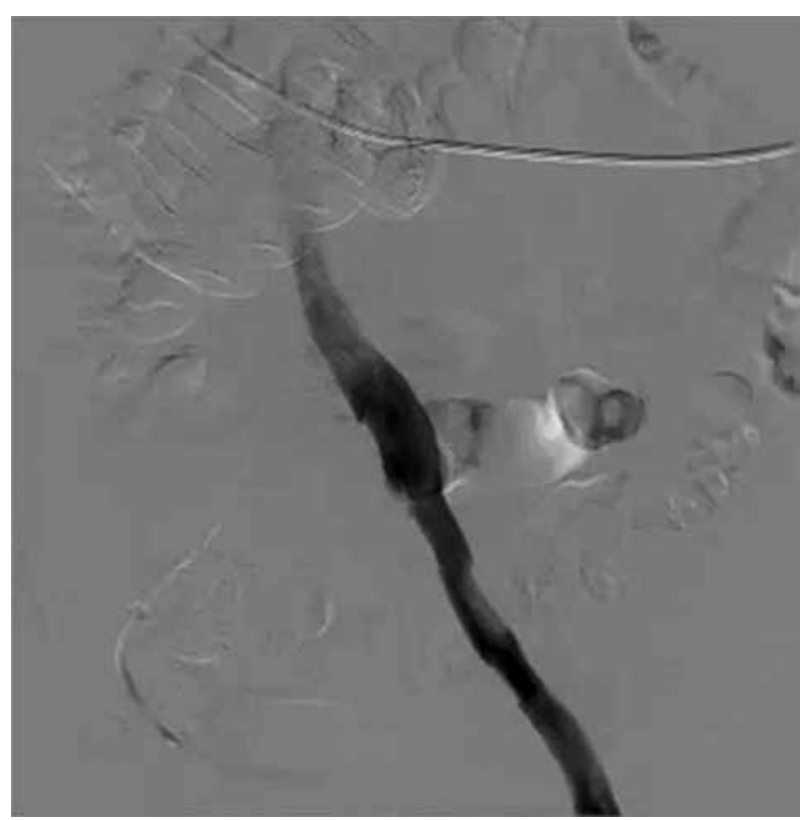

Fig. 12. Case 5 - The final effect in the venography: flow in left common and external iliac veins; placement on the back

obstacle in the iliac veins, probably tumour infiltration, could not be overcome. The procedure was discontinued, heparin treatment with a small therapeutic dose was continued, and compression therapy was applied. Due to the swelling of the limb, the hospitalisation was extended to eight days. In the post-hospital period, low-molecular-weight heparin was recommended without any time limit due to oncological history.

\section{RESULTS}

All patients who underwent aspiration thrombectomy in the local clinic, had anticoagulant treatment after the procedure with new oral anticoagulants (NOAC) - rivaroxaban $20 \mathrm{mg}$ for three months and compression therapy in the second degree of pressure. In the case of stent implantation, acetylsalicylic acid at a dose of $75 \mathrm{mg}$ was added. There are no randomised trials confirming the effectiveness of invasive methods in the treatment of proximal thrombosis and studies confirming the efficacy of anticoagulant therapy after such surgery. Guidelines for prevention, diagnostics, and therapy - Konsensus Polski 2017 recommends the use of heparins in a treatment dose in the period around the surgical intervention of oral anticoagulants from the group of vitamin $\mathrm{K}$ antagonists and continuing them for a period of six months [2]. The guidelines were published in the second half of 2017 after the above-described treatments and were not applied in the presented group. The use of new coagulants in this short observation proved to be effective in preventing thrombosis recurrence, and convenient for patients; it also does not 
Table 1. Patient treatment history

\begin{tabular}{|c|c|c|c|c|c|c|c|}
\hline $\begin{array}{l}\text { Sex } \\
\text { and } \\
\text { age }\end{array}$ & $\begin{array}{l}\text { Location of the blood clot and } \\
\text { significant examination }\end{array}$ & $\begin{array}{c}\text { Time of hospi- } \\
\text { talisation/time } \\
\text { from surgery } \\
\text { until discharge }\end{array}$ & $\begin{array}{l}\text { Time from } \\
\text { symptoms } \\
\text { to surgery }\end{array}$ & $\begin{array}{l}\text { Applied } \\
\text { procedure }\end{array}$ & $\begin{array}{c}\text { Possible } \\
\text { complications }\end{array}$ & $\begin{array}{l}\text { The effect } \\
\text { of treatment after } \\
1 \text { and } 3 \text { months }\end{array}$ & $\begin{array}{l}\text { Post-operative } \\
\text { recommenda- } \\
\text { tions }\end{array}$ \\
\hline $\begin{array}{l}\text { F } 19 \\
\text { A.P. }\end{array}$ & $\begin{array}{c}\text { Left subclavian axillary } \\
\text { and humeral vein. } \\
\text { Examination: } \\
\mathrm{Hb} 8.0 \mathrm{~g} \%, 6.7 \mathrm{~g} \%, 9 \mathrm{~g} \% \text {, } \\
\text { D-dimer } 1828 \mu \mathrm{g} \% \text {, } \\
\text { CRP } 77 \mathrm{mg} \% \text {, other within } \\
\text { normal limits }\end{array}$ & $8 / 1$ & $\begin{array}{c}15(7+8) \\
\text { days }\end{array}$ & $\begin{array}{l}\text { Aspiration throm- } \\
\text { bectomy, PTA + } \\
\text { stent + removal } \\
\text { of the first rib }\end{array}$ & $\begin{array}{l}\text { The need to } \\
\text { transfuse } 2 \mathrm{U} \text { of } \\
\text { red blood cells }\end{array}$ & $\begin{array}{l}\text { Full patency } \\
\text { of left axillary vein } \\
\text { and regression } \\
\text { of symptoms }\end{array}$ & $\begin{array}{c}\text { Rivaroxaban + } \\
\text { ASA + compres- } \\
\text { sion therapy }\end{array}$ \\
\hline $\begin{array}{l}\text { F } 41 \\
\text { B.B. }\end{array}$ & $\begin{array}{c}\text { Right iliac, external, } \\
\text { and femoral vein. } \\
\text { Examination: } \\
\text { leukopaenia } 213000 \text {, } \\
\text { Hb } 10 \mathrm{~g} \%, 7 \mathrm{~g} \%, 9 \mathrm{~g} \% \text {, } \\
\text { PLT } 130,000, \text { APC-R (+), LA (+) }\end{array}$ & $6 / 4$ & $\begin{array}{c}8(6+2) \\
\text { days }\end{array}$ & $\begin{array}{c}\text { Aspiration } \\
\text { thrombectomy + } \\
\text { fibrinolysis using } \\
\text { alteplase }\end{array}$ & $\begin{array}{l}\text { The need to } \\
\text { transfuse } 2 \mathrm{U} \\
\text { of red blood } \\
\text { cells due to } \\
\text { the loss of } \\
\text { morphology }\end{array}$ & $\begin{array}{l}\text { Full patency and } \\
\text { regression of symp- } \\
\text { toms }\end{array}$ & $\begin{array}{c}\text { Rivaroxaban + } \\
\text { compression } \\
\text { therapy }\end{array}$ \\
\hline $\begin{array}{l}\text { F } 19 \\
\text { P.N. }\end{array}$ & $\begin{array}{l}\text { Left iliac common, external, } \\
\text { and femoral vein. } \\
\text { Examination: } \\
\text { leukocytosis 164,000; } \\
\text { Hb 13.2 g\%; 9,7g\%, } \\
\text { PLT 320,000, } \\
\text { CRP } 57 \mathrm{mg} / \mathrm{l}, \\
\text { D-dimer } 2700 \mu \mathrm{g} \% \text {, anti- } \\
\text { thrombin III, protein C, APC-R in } \\
\text { the norm, S protein < 46\% (+), } \\
\text { suspicion of MTS }\end{array}$ & $3 / 2$ & $1 / 24 h$ & $\begin{array}{c}\text { Aspiration } \\
\text { thrombectomy + } \\
\text { stent at the site of } \\
\text { narrowing }\end{array}$ & None & $\begin{array}{l}\text { Full patency and } \\
\text { regression of symp- } \\
\text { toms }\end{array}$ & $\begin{array}{c}\text { Rivaroxaban + } \\
\text { ASA + compres- } \\
\text { sion therapy }\end{array}$ \\
\hline $\begin{array}{l}\text { M } 72 \\
\text { J.L. }\end{array}$ & $\begin{array}{l}\text { Left iliac common, external, } \\
\text { and femoral vein. } \\
\text { Examination: D-dimers 33,866, } \\
\text { leuk. 16,000, PLT 135,000, } \\
\text { Hb } 15.8 \text { g\%, } 8 \text { g\%, } 10 \mathrm{~g} \%\end{array}$ & $4 / 3$ & $1 / 24 h$ & $\begin{array}{l}\text { Aspiration throm- } \\
\text { bectomy }\end{array}$ & $\begin{array}{l}\text { The need to } \\
\text { transfuse } 2 \mathrm{U} \text { of } \\
\text { red blood cells } \\
\text { due to the loss } \\
\text { of morphology }\end{array}$ & $\begin{array}{l}\text { Full patency and } \\
\text { regression of symp- } \\
\text { toms }\end{array}$ & $\begin{array}{l}\text { Rivaroxaban } \\
20 \mathrm{mg}+ \\
\text { compression } \\
\text { therapy }\end{array}$ \\
\hline $\begin{array}{c}\text { M } 71 \\
\text { T.W. }\end{array}$ & $\begin{array}{l}\text { Left iliac common, external, } \\
\text { and femoral vein; initially, } \\
\text { the level of morphology was } \\
14.4 \mathrm{~g} \% \text { after surgery, } \\
10.0 \mathrm{~g} \% \text { did not require blood } \\
\text { transfusion }\end{array}$ & $5 / 2$ & $\begin{array}{c}6(3+3) \\
\text { days }\end{array}$ & $\begin{array}{c}\text { Aspiration } \\
\text { thrombectomy + } \\
\text { 24-hour Actilyse } \\
\text { infusion }\end{array}$ & None & $\begin{array}{l}\text { Full patency } \\
\text { and regression } \\
\text { of symptoms }\end{array}$ & $\begin{array}{l}\text { Rivaroxaban } \\
20 \mathrm{mg}+ \\
\text { compression } \\
\text { therapy }\end{array}$ \\
\hline $\begin{array}{l}\text { F } 64 \\
\text { S.S. }\end{array}$ & $\begin{array}{l}\text { Left iliac common, external, } \\
\text { and femoral vein. } \\
\text { Examination: } \\
\text { D-dimers } 36,581 \mu \mathrm{g} \% \text {, } \\
\text { leukocytes } 93,000 \text {, } \\
\text { PLT 219,000, Hb 12,9 g\%, } \\
\text { active cancer }\end{array}$ & $6 / 5$ & $1 / 24 h$ & $\begin{array}{l}\text { Aspiration throm- } \\
\text { bectomy probably } \\
\text { ineffective except } \\
\text { for thrombi, } \\
\text { tumour masses } \\
\text { that infiltrate the } \\
\text { vessels }\end{array}$ & None & $\begin{array}{l}\text { Prolonged hospitalisa- } \\
\text { tion due to oedema, } \\
\text { pain, and treatment }\end{array}$ & $\begin{array}{l}\text { Low-molecular- } \\
\text {-weight heparin } \\
\text { by body weight } \\
\text { + compression } \\
\text { therapy }\end{array}$ \\
\hline
\end{tabular}

require monitoring of the INR (the normalised prothrombin time) and taking care of the diet affecting the effectiveness of the drug. However, due to the innovative method of treatment used, the procedure after surgery requires many trials and tests to establish an unambiguous position and choice of the drug. Pharmaceutical treatment should always be supplemented with compression therapy.

\section{CONCLUSIONS}

Based on the data, it can be concluded that aspiration thrombectomy combined in some cases with transcatheter thrombolysis:

- allows for quick removal of thrombi and resection of veins while maintaining the proper function of venous valves, 
- leads to quick relief of symptoms, mainly swelling and pain,

- reduces hospitalisation time by half on average, and immobilisation at home, compared to conventional treatment,

- no significant bleeding complications were observed; blood transfusions were due to the decrease of haemoglobin below $7 \mathrm{~g} \%$,

- there were no deaths during its use,

- it prevents thrombus prolongation in the proximal and indirectly pulmonary embolism;

- it probably reduces the risk of developing a post-thrombotic syndrome, which requires further observation,

- the applied anticoagulant treatment after surgery with the use of NOAC in combination with ASA and compression therapy resulted in maintenance of vein patency for five months of observation of these patients,

- given the novel nature of the device, further observation is needed to demonstrate the safety and comparable efficacy of this method in the treatment of patients with acute DVT in short- and long-term studies, including randomised, controlled clinical trials before any recommendations for its use can be made.

\section{The authors declare no conflict of interest.}

\section{References}

1. Meissner MH, Gloviczki P, Comerota AJ, Dalsing MC, Eklof BG, Gillespie DL, Lohr JM, McLafferty RB, Murad MH, Padberg F, Pappas P, Raffetto JD, Wakefield TW, Society for Vascular Surgery, American Venous Forum. Early thrombus removal strategies for acute deep venous thrombosis: clinical practice guidelines of the Society for Vascular Surgery and the American Venous Forum. J Vasc Surg. 2012; 55: 1449-1462

2. Tomkowski W, Kuca P, Urbanek T, Chmielewski D, Krasiński Z, Pruszczyk P, Windyga J, Oszkinis G, Jawień A, Burakowski J, Dybowska M, Kęsik J, Zubilewicz T. Żylna choroba zakrzepowo-zatorowa - wytyczne profilaktyki, diagnostyki i terapii. Konsensus Polski 2017. Acta Angiol 2017; 23: 73-113.

3. Robertson L, McBride O, Burdess A. Pharmacomechanical thrombectomy for iliofemoral deep vein thrombosis. Cochrane Database Syst Rev 2016; 11: CD011536.

4. Kohi MP, Kohlbrenner R, Kolli KP, Lehrman E, Taylor AG, Fidelman N. Catheter directed interventions for acute vein thrombosis. Cardiovasc Diagn Ther 2016; 6: 599-611.

5. Rich K. Iliofemoral deep vein thrombosis: Percutaneous endovascular treatment options. J Vasc Nurs 2015; 33: 47-53.

6. Marine L, Urbina J, Bergoeing M, Valdés F, Mertens R, Kramer A. Mechanical and pharmacomechanical trombolysis in deep venous thrombosis with no clinical response to conventional treatment. Rev Med Chil 2017; 145: 63-71.

7. Amin VB, Lookstein RA.Catheter-directed interventions for acute iliocaval deep vein thrombosis. Tech Vasc Interv Radiol 2014; 17: 96-102.

8. Moudgill N, Hager E, Gonsalves C, Larson R, Lombardi J, DiMuzio P. May-Thurner syndrome: case report and review of the literature involving modern endovascular therapy. Vascular 2009; 17: 330-335.
9. Kim IS, Jo WM, Chung HH, Lee SH. Comparison of clinical outcomes of pharmacomechanical thrombectomy in iliac vein thrombosis with and without May-Thurner syndrome. Int Angiol 2018; 37: 12-18.

10. Xue GH, Huang XZ, Ye M, Liang W, Zhang H, Zhang JW, Zhang BG. Catheter-directed thrombolysis and stenting in the treatment of iliac vein compression syndrome with acute iliofemoral deep vein thrombosis: outcome and follow-up. Ann Vasc Surg 2014; 28: 957-963.

11. Berencsi A, Dósa E, Nemes B, Hüttl K, Legeza P, Oláh Z, Kristóf V, Acsády G, Sótonyi P. Endovascular treatment of acute iliofemoral deep venous thrombosis - our results with catheter-directed thrombolysis and AngioJet. Magy Seb 2017; 70: 24-31.

12. Liu G, Qin J, Cui C, Ye K, Shi H, Liu X, Yin M, Huang X, Lu M, Jiang M, Li W, Lu X. Comparison of Direct Iliofemoral Stenting Following AngioJet Rheolytic Thrombectomy vs Staged Stenting After AngioJet Rheolytic Thrombectomy Plus Catheter-Directed Thrombolysis in Patients With Acute Deep Vein Thrombosis. J Endovasc Ther 2018; 25: 133-139.

13. Yuksel A, Tuydes O. Midterm Outcomes of Pharmacomechanical Thrombectomy in the Treatment of Lower Extremity Deep Vein Thrombosis With a Rotational Thrombectomy Device. Vasc Endovascular Surg 2017; 51: 301-306.

14. Rodríguez LE, Aboukheir-Aboukheir A, Figueroa-Vicente R, Soler-Bernardini H, Bolanos-Avila G, Torruella-Bartolomei LJ, Comerota AJ, Martinez-Trabal JL. Hybrid operative thrombectomy is noninferior to percutaneous techniques for the treatment of acute iliofemoral deep venous thrombosis. J Vasc Surg Venous Lymphat Disord 2017; 5: 177-184.

15. Sapoval M, Del Giudice C. Life post - ATTRACT: The new challenge of DVT treatment. In: Clearing the clot. New horizons in deep vein thrombosis treatment Vascular News (Suppl.) 2017: 2.

16. Lichtenberg M, Bisdas T, van den Berg JC, Le Bras Y, Petitpierre F, Wolf F. Indygo Percutaneus Mechanical Thrombectomy System. Endovascular Today 2016; 4: 76-83. 